\title{
Production indices for dual purpose cattle in central Brazil
}

\author{
Concepta McManus ${ }^{1,2,3}$, Helder Louvandini ${ }^{4}$, Helena Cristina Carneiro ${ }^{1}$, Paulo Ricardo \\ Martins Lima ${ }^{1}$, José Braccini Neto ${ }^{2}$ \\ ${ }^{1}$ Postgraduate course in Animal Sciences, Faculdade de Agronomia e Medicina Veterinária, Universidade de Brasília, Brasília, DF \\ 70910-900, Brasil. \\ 2 Universidade Federal do Rio Grande do Sul, Departamento de Zootecnia, Porto Alegre, RS, Brasil. \\ ${ }^{3}$ Vice Coordenadora INCT-IGSPB - CNPq - FAPEMIG. \\ ${ }^{4}$ Centro de Energia Nuclear na Agricultura, Universidade de São Paulo, Piracicaba, SP, Brasil.
}

\begin{abstract}
This study examined the effects of crossbreeding low genetic potential cows of Bos indicus origin characterized by Gyr crossed with Holstein-Friesian and Simmental bulls to produce animals in a low input dual purpose system. The farm is situated near Brasilia, in the savannah region of Brazil. The climate of the region is classified as Aw by Köppen. Data was available on 1580 calvings and completed lactations of cows with three genetic types: Gyr, Holstein-Friesian $\times$ Gyr and Simmental $\times$ Gyr. The bulls ran with the cows all year round and the diet comprised of pasture (mainly Brachiaria and Andropogon) during the summer (rainy season) and milled sugar cane with added urea during the winter (dry season). A mineral salt mixture was available ad libitum. Data was analysed using Statistical Analysis System. The results show that, under low input management conditions, the crossbred cows produce approximately twice the volume of milk per lactation, calve at a younger age and have a shorter open period, but there are no significant differences between crosses for growth rates of the calves or body condition of the cows. In this system, crossbred cows had production higher indices than zebu cattle. The best indices were found for cows calving in the rainy season (September to December) and thinner cows (with body condition 3-5 on a scale of 9).
\end{abstract}

Key Words: beef cattle, crossbreeding, milk, productivity, ratios, real fertility

\section{Introduction}

Cattle production in Brazil shows a high degree of diversity in terms of the technological and efficiency levels on farms. The production indices for Brazil central are low, with a $54 \%$ calving rate, $50 \%$ weaning rate, mortality of $8 \%$, calving intervals of up to 24 months and heifers calving at 3 years of age or more. Milk productions are in the region of $2.5 \mathrm{~kg} / \mathrm{day} / \mathrm{cow}$ in lactation, concentrated in the rainy season and lactation periods tend to be short. The centre-east of the country produces $15 \%$ of the total milk production in Brazil (Gomes, 2001). The mean milk production depends on farm size and farming system but is approximately $1172 \mathrm{~kg} / \mathrm{cow} /$ year (IBGE, 2004) with extensive systems being least productive (Assis et al., 2005). In this region, milk production is from crossbred zebu animals reared at pasture with little technology and low production costs (Facó et al., 2002). According to Ortega et al. (2007) dual purpose cattle systems are traditional in Latin American countries, and are characterized by low inputs and crossbred cattle.

The centre-west of the country has little tradition in milk production (McManus et al., 2008) but a significant number of beef cattle farms in the region explore, to a greater or lesser degree, the milk production of the cows (Restle et al., 2005). These cows have low milk producing potential, but the milk production is an important component of the farm profit, creating a monthly cash flow which covers the more immediate costs of the farming enterprise. Evans et al. (2004) concluded that dual purpose systems using crossbred animals are much more economical than pure-bred Holstein. In general, recorded herds are a minority leaving large gaps in our knowledge about cattle systems in the central region of Brazil. According to Barbosa \& Bueno (2000) only 9\% of cows are milked in Brazil and dual purpose systems, while not important for meat production, are responsible for almost $25 \%$ of milk production, reaching $50 \%$ in the Northern and Center West regions. Most of the research in the region is based on systems with high inputs, using cattle of high genetic potential, in general, unavailable to the small producer (Madalena et al., 2002).

A major problem in using animal production data is how to make maximum use of results produced in isolation. Although considerable work was being undertaken on the productivities of cattle types, little comparative information 
had become available (FAO, 1976). The aim of this study was to compare production and reproduction traits of three genetic groups of cows (Gyr and its crossbreds with Holstein and Simmental).

\section{Material and Methods}

The research farm is situated near Brasilia, in the savannah region of Brazil, with the climate of the region classified as Aw by Köppen (1948), having a mean annual temperature of $21.1^{\circ} \mathrm{C}$ with absolute minimum and maximum temperatures of $1.6^{\circ} \mathrm{C}$ and $34.5^{\circ} \mathrm{C}$ respectively, and relative humidity of $68 \%$. The climate is characterised by two well defined seasons, rainy, which received almost all the precipitation (October to April) and dry (May to September) when rainfall is negligible.

Data was available on 1580 calvings over a ten year period and completed lactations of cows of three genetic types: Gyr, Holstein-Friesian × Gyr and Simmental × Gyr. The original stock was chosen from a pool of cows, not for their genetic potential, but because they adapted well to the milking system. Manual milking was carried out once a day (in the morning). The calves are allowed to suckle for a short time before milking to stimulate let down, are tied at the legs of the cow during milking and only after milking are allowed to suckle freely. Calves were maintained with the cows until 3 months of age. Weaning occurred at approximately 7 months of age. Milk production was measured every 14 days. The bulls ran with the cows all year round. Culling of the cows was on the basis of calving interval (greater than 450 days) and the ability to adapt to the system. Condition score of the cows was evaluated at calving and weaning using a 1 to 9 scale as described in Wildman et al. (1982).

The diet comprised of pasture (Brachiaria decumbens, Brachiaria ruziziensis, Brachiaria brizantha c.v. Marandu, and Andropogon gayanus c.v. Planaltina, as well as natural pastures of Melinis menutiflora e Hyparhenia rufa.) during the summer (rainy season) and milled sugar cane with added urea (1\%) during the winter (dry season). A mineral salt mixture was available ad libitum. The animals were put in the pastures which, according to visual appraisal, were in the best conditions to be grazed. The grazing density used was approximately $1 \mathrm{AU} / \mathrm{ha}$.

The cows were vaccinated for Foot and Mouth Disease twice a year and in the 8th month of pregnancy. New-born calves were vaccinated against pneumoenterites. Heifers were vaccinated at 3 and 8 months against Brucellosis and all calves were vaccinated against black leg, gas gangrene and enterotoxemia at six months of age. Only young animals were dosed at weaning, and from there on in May, July and
December, until 36 months of age. Ectoparasites, especially screw worm and horn fly, were treated sporadically with phosphoric compounds.

The data was analysed using the GLM (General Linear Model) and CORR (Correlation) procedures of SAS (Statistical Analysis System). The dependant variables included lactation period, days open, calf weaning weight, condition score at calving, age at first calving and total production corrected for 305 days. Independent variables fixed effects included calving number (CN), month and year of calving, genetic group of the cow (GG), sex of the calf and condition score of the cow at calving. Lactation length and birth weight of the calf were included as covariables, where appropriate. Only cows with completed lactations were included in the analysis. Data was available on daily average milk yield (AMY), total lactation milk yield (TMY), last milk yield before drying of (LMY) and milk yield corrected for 305 days lactation (M305), lactation period (LP), calf birth (BW) and weaning weight (WW), calving interval (CI), cow weight and body condition score at calving (CWC and BSC) and weaning (CWW and BSW), age of heifer at first calving (AFC). Metabolic weight of the cow was calculated at calving $\left(\mathrm{CWC} \mathrm{C}^{0.75}\right)$ and weaning $\left(\mathrm{CWW}^{0.75}\right)$. From these several indices were calculated:

i) Real fertility $(\mathrm{RF})=(\mathrm{WW} \times 365 / \mathrm{CI})($ Lôbo, 1994);

ii) Birth weight ratio $(\mathrm{BWR})=(\mathrm{BW} / \mathrm{CWC})$ (Alencar et al., 1997);

iii) Weaning weight ratio $(\mathrm{WWR})=(\mathrm{WW} / \mathrm{CWW})$ (Alencar et al., 1997);

iv)Weaning weight ratio2 $($ WWR2) $=$ WW/CWC (McManus et al., 2002);

v) Cow productivity index (CPI) = calf weight per cow per year + annual milk yield (FAO/ILCA/UNEP, 1980); Milk yield extracted per cow per year was transformed to its live-weight equivalent to a ratio of 9 (assuming that it takes $9 \mathrm{~kg}$ of milk to produce $1 \mathrm{~kg}$ of live weight in the calf) and added to the calculated calf weight. Finally, the result was expressed per $100 \mathrm{~kg}$ live weight of cow to take into account maintenance requirements (Drewry et al., 1959). These were CPIC $=(\mathrm{WW}+(\mathrm{TMY} / 9)) / \mathrm{CWC}^{0.75}$ and $\mathrm{CPIW}=(\mathrm{WW}+(\mathrm{TMY} / 9)) / \mathrm{CWW}^{0.75}$.

\section{Results and Discussion}

In general lactation number, genetic group, month and year of calving as well as body condition affected milk traits and reproductive indices (Table 1). This is in agreement with Montiel et al. (2007) looking at dual purpose cattle in Mexico, but average milk production in the present study were higher ( $6.26 \mathrm{~kg} /$ day) than seen by these authors 
(4 kg/day) and similar to Parra et al. (1999) in Venezuela (6.5 kg/day). This may be due to genetic group and feeding policies.

According to Barbosa et al. (1994) the ideal lactation length in milk cows should be 305 days. Here the mean 262 days, much lower than the desired length, but in line with that found by Gloria et al. (2010) for crossbred HolsteinZebu cattle in Brazil.

Calving number had a significant effect on the lactation milk production and weight traits, not affecting last milk yield, body score at calving or weaning weight. Calving number also had a significant influence on lactation period, where heifers had lactation periods close to "normal” (297 days) and older cows had reduced lactation periods (252.35 days), maybe suggesting a prolonged service period for younger cows. Older cows have been seen to wean heavier calves due to improved maternal ability which may influence milk productivity (Campello et al., 1999). The shortening of the lactation period until the $3^{\text {rd }}$ calving suggests longer service periods in the younger cows, maybe due to the fact that the cow herself is still in the development phase (Figure 1 and 2). After this initial decrease there is a period of stabilisation until the $6^{\text {th }}$ calving, when the cow is approximately 10 years old, and followed by an increase in the following years, suggesting that only truly efficient animals remained in the herd. The others are culled for various reasons including whether or not they adapt to the milking system or interval between calvings of greater than 450 days. Older cows had a tendency for the lactation period to decrease, probably due to advanced age of the cow and problems with senility.

The length of lactation period varied due to breed/ genetic group. In several studies carried out in Central and southern American countries, using various levels of degrees of Bos taurus in the cows, results show that the higher the proportion of Zebu the shorter the lactation length and lower the milk production (Madalena et al, 1978), as well as lower calving intervals and ages at first calving (Freitas et al., 1980). Ruas et al. (2007) found significant differences between Gyr × Holstein (306 days) and Guzerat $\times$ Holstein (265 days) cows for lactation length. Working with mixed breed cows with various levels of HolsteinFriesian cows, Lemos et al. (1997) noted an increase in the lactation period, with an increase in the proportion of Holstein-Friesian in the cows. The degree of crossing should not exceed $0.50-0.75$ in hot climates, without protection from the climate, as the heat stress factor as well as general feeding, management and parasite loads, lead to a decrease in the production of the crossbred cow.

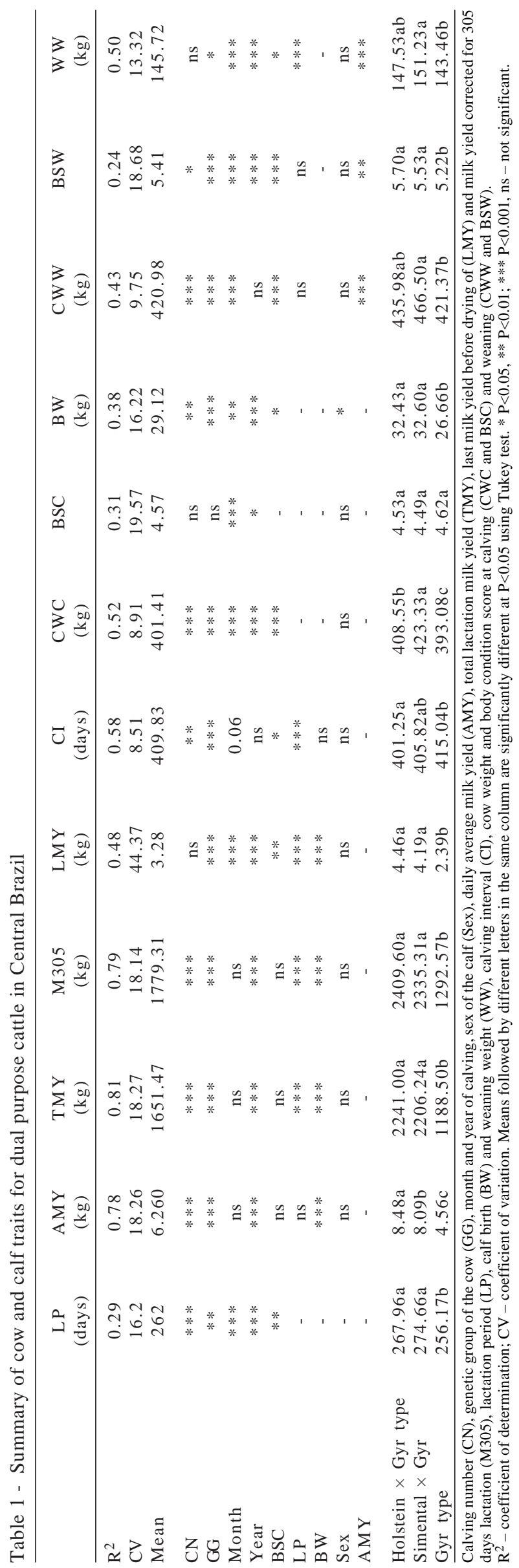

R. Bras. Zootec., v.40, n.7, p.1576-1586, 2011 
There was a tendency of lactation period to decrease over the years, possibly due to a shortening of the service period. The service period was not measured as bulls were kept with the cows constantly and heats were not observed. The reduction of lactation period in recent years may reflect an auto-defence of the cows, trying to recover for the next calving, since the weaning process is predominantly natural, the proper cow rejecting the calf and therefore milk production ceased.

The lactation period plays a very important role in the economic result of the dairy enterprise. In the present work the lactation period was $258.20 \pm 68.32$ days, well
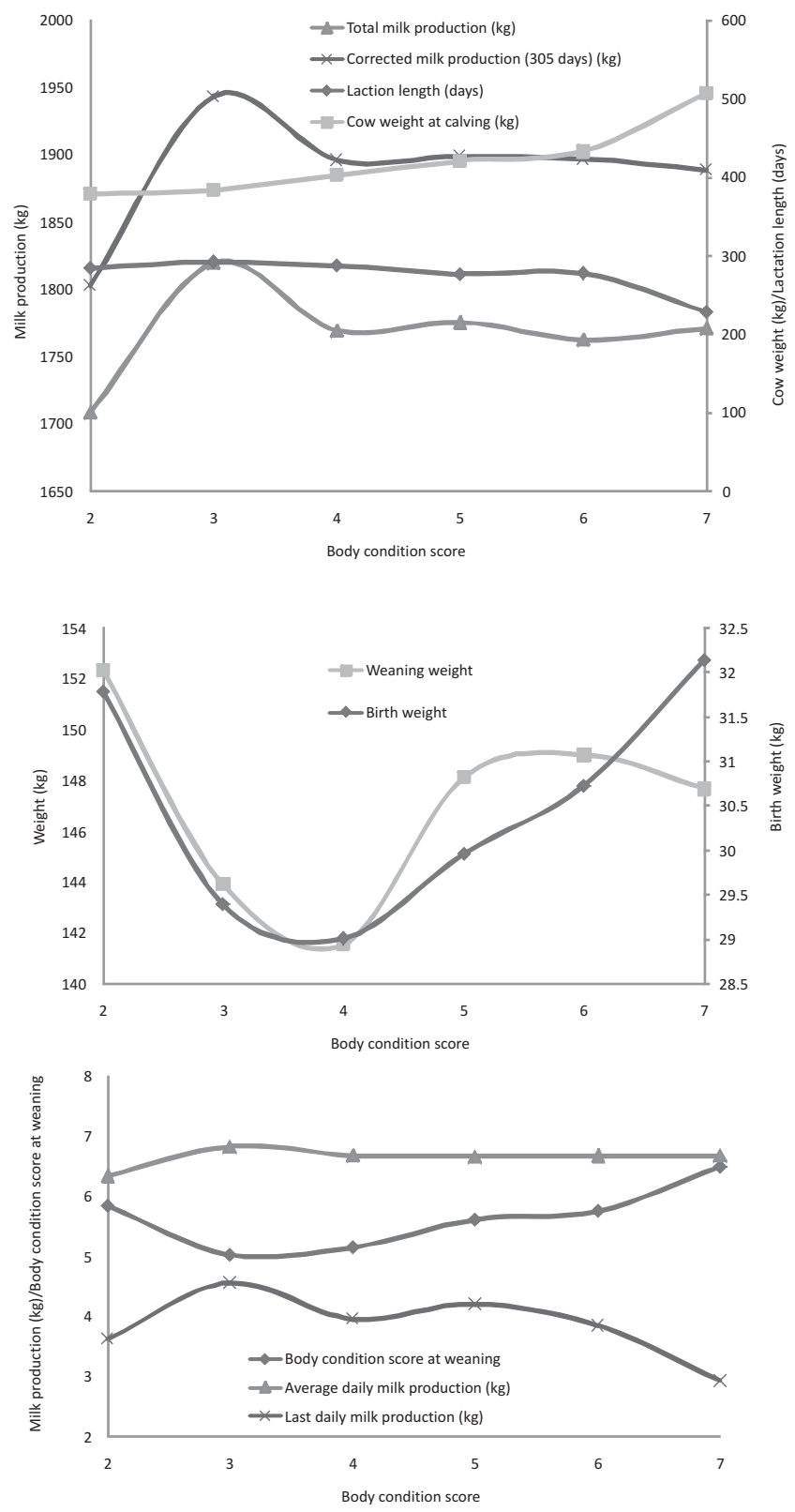

Figure 1 - Effect of cow body condition score at calving on milk production, lactation length, calf weight and cow body condition at weaning. below the recommended of 305 days. Similar results are found in other works using this type of cattle (Madalena et al., 1983). Various factors result in the increase or decrease of the lactation period, including (Table 1) calving number, month and year of birth and breed. Zebu cattle have shorter lactation lengths than Bos taurus cattle and nutritional factors may have influenced lactation period.

The mean calving interval (CI) in the present study was 404.09 ( \pm 65.33 ) days. The service period was therefore approximately 128 days. The CI in recent years was lower than the overall mean, closer to 365 days, with a service period of 81 days. In the same period milk production
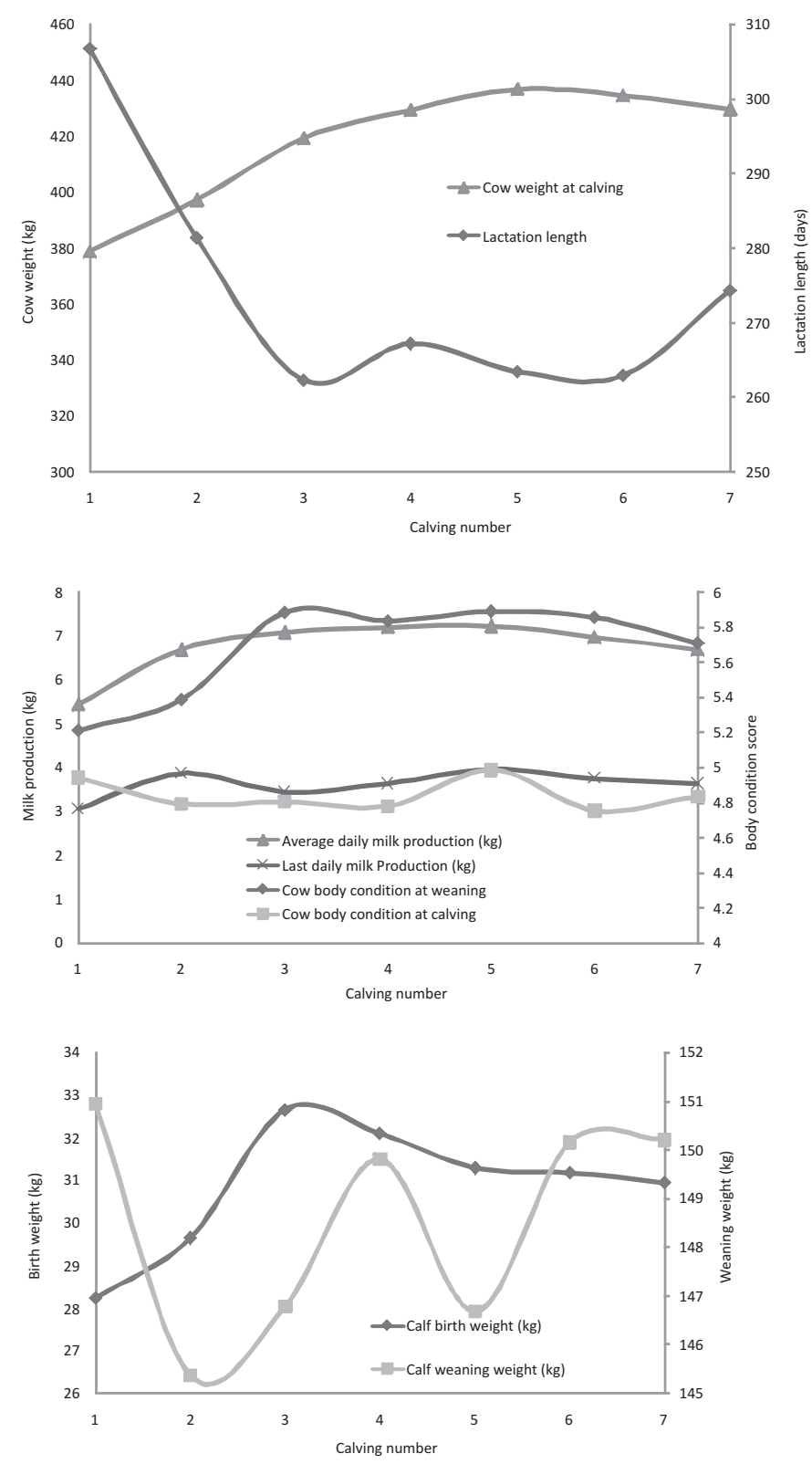

Figure 2 - Effect of calving number on cow weight, lactation length, milk production and calf weight in a dual purpose system.

R. Bras. Zootec., v.40, n.7, p.1576-1586, 2011 
corrected for 305 days rose from $1663 \mathrm{~kg} /$ cow to $2263 \mathrm{~kg} / \mathrm{cow}$. This indicates a significant improvement in herd management along with culling sub-fertile animals. An improvement in reproductive efficiency of the herd and, in consequence, greater herd productivity is not in detriment of milk production, but implies improved efficiency in the whole milk and meat production system. Year of calving had a significant effect $(\mathrm{P}<0.05)$ on all the traits studied except calving interval and cow weight at calving, improving along the years as cows that did not adapt to the system were eliminated.

According to Perotto et al. (2006a), calvinginterval for beef cattle in the range of 12 to 13 months are important as it means that the herds in question can attain greater efficiency with one calf per cow per year. Calving interval here was 13.6 months (409.83 days), similar to that found by Facó et al. (2005) with Gyr $\times$ Holstein cows and less than found by McManus et al. (2002) and Perotto et al. (2006b), who found 471 days 477 days respectively. This may have been influenced by a higher body condition score than found by McManus et al. (2002). On the other hand Guimarães et al. (2002) did not observe an effect of genetic group on calving interval with various groups of Holstein $\times$ Gyr.

Studies show that Bos indicus type cattle tend to be more problematic in terms of reproduction than crossbred cows (Euclides Filho, 1995). They take longer to return to service and require more inseminations per conception. Milking herds usually receive concentrate as a supplement during the lactation period, whereas here the production is based at pasture. The crossbred cattle had a somewhat longer lactation period and shorter calving interval, probably due to genetic differences between the cattle types. Crossbred cows were being dried off at the mean production level for the Gyr cows (Table 1). Over the years there is a tendency for the production of all three genetic groups to increase, the crossbred cattle always being superior, approximately double the production of the Gyr cows (data not shown).

Those cows which calved in the transition between dry/wet season (September to December) showed shorter lactation periods ( $244 \pm 19$ vs $287 \pm 25$ days), than those cows that calved in the dry season (May to August) in function of the higher quantity and quality pasture available after calving, which also resulted in lower calving intervals (396 \pm 23 vs $447 \pm 27$ days). This may also indicate that the quantity or quality of supplementation offered was not sufficient to meet cow needs, that cows reduced their forage intake during the period of supplementation (Montiel et al., 2007) or heat stress during the dry season may reduce feed and energy intake, as well as cause increases in respiratory rate and sweating, leading to the situation described above (McManus et al., 2009). The longer lactation periods seen above may indicate longer service periods (Teodoro et al., 1993, 1994). Seasonal variation in the establishment of pregnancy is well documented (López-Gatius, 2003) and research has shown that the effects of heat stress are less severe on animals which produce less heat (heifers and cows of breeds which produce less milk). The effect of heat stress during the last trimester of pregnancy is also shown to affect milk yield (Collier et al., 1992). Intense solar radiation can also provide a source of heat and exacerbate the problem (Hansen et al., 1992). Cows which calve in late summer pass the greater part of their lactation in the dry period exposed to high solar radiation and poor pasture thereby reducing their overall milk yield. As above, calving intervals tend to be higher in the months of high radiation and poor pasture quality.

In addition to lactation period, total milk production is also an important indicator of efficiency for the farm. Mean milk production per lactation here was $1,651.47 \pm 697.17 \mathrm{~kg}$ of milk, well below the mean for pure European breeds, and even for mixed breeds and pure-bred Bos indicus where concentrates have a fundamental role to play in the complementation of nutrients for the herd, increasing the milk production and is principally used where milk is the principal product. Otherwise, in systems where milk is a component of the whole production system feeding is based on pasture with a small chopped sugar cane in the dry season, the milk production is more than reasonable.

Average milk yield was $6.26 \mathrm{~kg} / \mathrm{head} / \mathrm{day}$, this being higher than the national mean value for the national Brazilian and Center West region which were $5.61 \mathrm{~kg} / \mathrm{head} /$ day and $4.0 \mathrm{~kg} / \mathrm{head} /$ day respectively (FNP Instituto, 2008). The last recorded milk production before drying off was $3.28 \mathrm{~kg} / \mathrm{head} /$ day, which was approximately $50 \%$ of average daily milk yield, this being close to mean herd production in the region. Crossbreeding is therefore a viable practice to increase milk production in the region, as crossbred animals produced more milk than the zebu cattle. According to Restle et al. (2005), crossbred cattle produce more milk due to heterosis and additive gene effects as well as pleiotropy. Ortega et al. (2007) pointed out that milk production is one of the most important traits for improving efficiency in dual purpose cattle systems.

Mean daily production was affected by calving number, breed, year of calving and birth weight of the calf. In the case of milk production for 305 days, the lactation period was also significant. In both cases, heifers were lower and increased until the $5^{\text {th }} / 6^{\text {th }}$ lactation. Campos (1987) also showed that greater lactations are in cows between 5 and 12 years old. 
Mixed breed cows (Bos taurus $\times$ Bos indicus) produced almost double the amount of milk of pure Bos indicus cows. Body condition score at calving did not influence milk production indicating that the cows were in adequate condition at calving, the mean body condition score was 4.57. On the scale of 1 to 9 , only scores from 3 to 7 were registered, with only 15 animals with score 7 . The lack of effect of this trait was probably due to the lack of very fat or very thin cows. The milk production here increased from $5.81 \pm 0.92 \mathrm{~kg}$ in the first year to $7.38 \pm 1.08 \mathrm{~kg}$ in 2005 , indicating an improvement in herd management as well as the quality of the cows.

Calf weight affected the milk production of the cow. Since the calves continued suckling during the lactation period, it is to be expected that larger calves demand more of the cow thereby leaving less milk to be extracted at the time of milking. The effect of suckling on delaying oestrus and subsequent insemination success in cows, especially Bos indicus, is well documented (Karg, 1980). Charolais $\times$ Zebu cows showed higher conception levels than zebu cows in the 180 days after calving (Madalena \& Hinojosa, 1976) as a result of the crossbred cows returning to service 58 days earlier than their zebu counterparts and the zebu cows having abnormally long oestrus cycles.

The fact that the Bos indicus type cow needs the presence of the calf to stimulate milk let down (Coulibaly \& Nialibouly, 1998), may be an important factor affecting calf growth. It is possible that the initial suckling stimulus is not sufficient for the Bos indicus cow fully release the milk, the greater milk let down occurring with the second posterior stimulus, when the calf is allowed to suckle freely.

The mean cow body condition at weaning was 5.41, higher than that found by McManus et al. (2002) who found 4.15 in the same region with crossbred beef cows. This was higher than that found for that at calving which was 4.57. This means that at weaning the cows had fat reserves even after producing a calf and milk. According to Fries \& Albuquerque (1999), better birth indices are found when the cows have intermediate body condition score from calving to weaning, avoiding cattle that are either very fat or very thin, which are inefficient in reproductive terms. Cow metabolic weights followed the same trends as normal weights at calving and weaning (Table 2).

Mean calf birth weight was $29.12 \mathrm{~kg}$, higher than those found by McManus et al. (2002), which was $25.51 \mathrm{~kg}$ but similar to those found by Mendonça et al. (2003) with crossbred cattle (30.41 $\pm 0.66 \mathrm{~kg})$. The crossbred calves were heavier than the Gyr (Table 1). BW was influenced by calving number, genetic group, month and year of calving, and calf sex agreeing with McManus et al. (2002).

Milk production increased up to the $5^{\text {th }}$ calving,falling to the $9^{\text {th }}$. This is in general agreement with authors studying Holstein-Friesian (Queiroz et al., 1986) and Gyr cattle (Ramos, 1984) in Brazil kept solely for milk production. Calf weaning weight showed no particular pattern with

Table 2 - Summary of analysis of variance for ratios and indices calculated from production data in dual purpose cattle in a farm in the Distrito Federal region in Brazil

\begin{tabular}{|c|c|c|c|c|c|c|c|c|}
\hline & BWR & WWR & WWR2 & $\mathrm{CWC}^{0.75}$ & $\mathrm{CWW}^{0.75}$ & CPIC & CPIW & $\mathrm{RF}$ \\
\hline $\mathrm{R}^{2}$ & 0.32 & 0.83 & 0.66 & 0.55 & 0.38 & 0.83 & 0.79 & 0.84 \\
\hline CV & 17.92 & 9.10 & 13.52 & 6.65 & 7.69 & 14.93 & 16.30 & 9.06 \\
\hline Mean & 0.07 & 0.36 & 0.350 & 89.74 & 92.95 & 20.02 & 19.21 & 108.83 \\
\hline $\mathrm{CN}$ & ns & $* * *$ & $* * *$ & $* * *$ & $* * *$ & $* * *$ & $* * *$ & 0.08 \\
\hline GG & $* * *$ & $* * *$ & $* * *$ & $* * *$ & $* * *$ & $* * *$ & $* * *$ & $* * *$ \\
\hline Month & $* * *$ & $* *$ & $* *$ & $* *$ & $* * *$ & $*$ & ns & $*$ \\
\hline LP & ns & $*$ & ns & $*$ & ns & $* * *$ & $* * *$ & $* * *$ \\
\hline WW & $*$ & $* * *$ & $* * *$ & $*$ & 0.09 & $* * *$ & $* * *$ & $* * *$ \\
\hline Sex & * & 0.09 & ns & ns & ns & ns & ns & ns \\
\hline AMY & - & - & - & - & - & - & - & - \\
\hline Holstein $\times$ Gyr type & $0.0803 a$ & $0.3644 \mathrm{a}$ & $0.3375 b$ & $91.00 \mathrm{~b}$ & $96.06 \mathrm{~b}$ & $26.23 a$ & $24.80 \mathrm{a}$ & $112.05 a$ \\
\hline Simental $\times$ Gyr & $0.0772 \mathrm{a}$ & $0.3604 \mathrm{a}$ & $0.3358 \mathrm{~b}$ & $93.37 \mathrm{a}$ & $98.58 \mathrm{a}$ & $25.39 b$ & $24.12 \mathrm{a}$ & 110.99 \\
\hline
\end{tabular}

Calving number (CN), genetic group (GG), body condition score at calving (BSC), lactation period (LP), weaning weight (WW), daily average milk yield (AMY), body weight ratio (BWR), weaning weight ratio (WWR), cow weight at calving (CWC), cow weight at weaning (CWW), cow productivity index at calving (CPIC), cow productivity index at weaning (CPIW), real fertility (RF).

$\mathrm{R}^{2}$ - coefficient of determination; CV - coefficient of variation. Means followed by different letters in the same column are significantly different at $\mathrm{P}<0.05$ by Tukey test. $* \mathrm{P}<0.05 ; * * \mathrm{P}<0.01 ; * * * \mathrm{P}<0.001$; ns-not significant. 
relation to calving number. European-Zebu heifers were younger than their Zebu counterparts at first calving, this trait improving over the years of the experiment.

The crossbred cows were heavier than the Gyr type cows (Table 1) but they were considerably lighter than Holstein $\times$ Gyr cows studied by Martins et al. (2004) of $540 \mathrm{~kg}$. The Holstein $\times$ Gyr cows were of similar weights to the crossbred cows used by Vercesi Filho et al. (2007).

In general, cow body condition affected calving interval and lactation period as well as cow and calf weights. Cow weight and body condition are influenced by the cow's nutritional status as condition score reflects nutritional status during pregnancy. Heavier weights and condition scores have been correlated with greater milk production (Franzo et al., 2001). In the present case cow weight but not condition affected milk production. Cows genetically inclined to have higher condition scores during the lactation are reported to have fewer days to first service (DFS), fewer services per conception (SPC) and a shorter calving intervals than cows that are genetically thin (Dechow et al., 2001; Pryce et al., 2001). The genetic correlation between energy balance and first luteal activity was reported to be moderately negative after adjustment for yield (Veerkamp et al., 2000). Additionally, bulls that sire daughters with high dairy form scores (and likely more angular and thin) have daughters with higher incidences of metabolic, reproductive and foot and leg diseases (Hansen et al., 2002). Higher loss in body condition from calving to weaning was associated with an increase in days to first service (Dechow et al., 2003).

Month or season of calving affects calf weight and milk production as feed quality at pasture tends to decrease in the dry season (Cubas et al., 2001). Cardoso et al. (2000) showed that highest milk production was with spring calving cows (September to November), which receive better quality and quantity feed, produce more milk and feed their calves better. Souza et al. (2006) showed that cows calving as early as July may benefit from the improved pasture in the spring.

Calf sex did not influence any of the milk or weight traits except birth weight, in agreement with other studies in milking cows (Oliveira et al., 2007). Only the milk left at the end of milking was available to the calf which may have restricted calf growth. Nevertheless, weaning weight was on average $145.72 \mathrm{~kg}(144.68 \pm 26,97 \mathrm{~kg}$ for females and $146.75 \pm 25.83 \mathrm{~kg}$ for males), higher than the $132.99 \mathrm{~kg}$ found by McManus et al. (2002), but lower than the $178 \mathrm{~kg}$ and $185 \mathrm{~kg}$ found in Nellore cattle by Campello et al. (1999), respectively. Once again the crossbreds were heavier than the pure breeds. Perotto et al. (2006b) did not observe any influence of calf sex on milk production traits. Weaning weight was influenced by genetic group, month and year of calving, body condition score at calving, daily average milk yield and lactation length. It was not affected by calving number, in agreement with McManus et al. (2002), but contrary to Campello et al. (1999), where older cows had heavier calves due to an increase in maternal ability with age.

Real fertility was influenced by genetic group, month of calving, condition score, lactation period and calf weaning weight (Table 2). McManus et al. (2002) and Campello et al. (1999) also found a significant effect of year and calving number. The mean was $108.83 \mathrm{~kg} /$ year which was lower than that found in a beef herd by McManus et al. (2002), probably due to the lower milk available to the calves. Crossbred cows had higher indices than Gyr, and Holstein crosses being more productive at calving than the other groups (Table 2).

Cow productivity indices using metabolic weights at calving and weaning were influenced by almost all effects examined, with the Gyr type cattle being significantly less productive than the other two genetic groups. These indices include both milk and calf production. This means that in this type of production system crossbred cattle are preferable to Gyr type.

The mean body weight ratio at calving was 0.07 , in agreement with the 0.07 and 0.069 found by McManus et al. (2002) and Alencar et al. (1997), respectively. According to McManus et al. (2002) the effect of the dam is pronounced because maternal weight influences calf weight. The mean weaning weight ratio was 0.36 , close to that found by McManus et al. (2002) of 0.354 in beef cattle. Month influenced this trait as calves had better pasture available in certain times of the year leading to higher weaning weights (Campello et al., 1999).

Condition score of the cow at calving did not affect birth weight ratio (Figure 3), in agreement with McManus et al. (2002). Body score is an efficient means to evaluate the nutritional state of the cow as it influences directly production and reproduction traits (Randel, 1990). This author stated that calves fed with low nutritional and energetic diets had lower weaning weights, higher age at puberty, a large post partum anestrous and service period resulting in greater calving interval and lower real fertility. Selection of animals on weaning weight selects for heavier adult animals with higher maintenance costs and later finishing (Silveira et al., 2004). Females may also have lower reproductive efficiency, with an increase in age at first calving.

Pearson correlations between Cow Productivity Indices were high $(>0.87$ ) and in general $>0.95$ (Table 3 ). Therefore the index can be calculated using cow weight at weaning or calving, and corrections made to equal milk yield to calf 


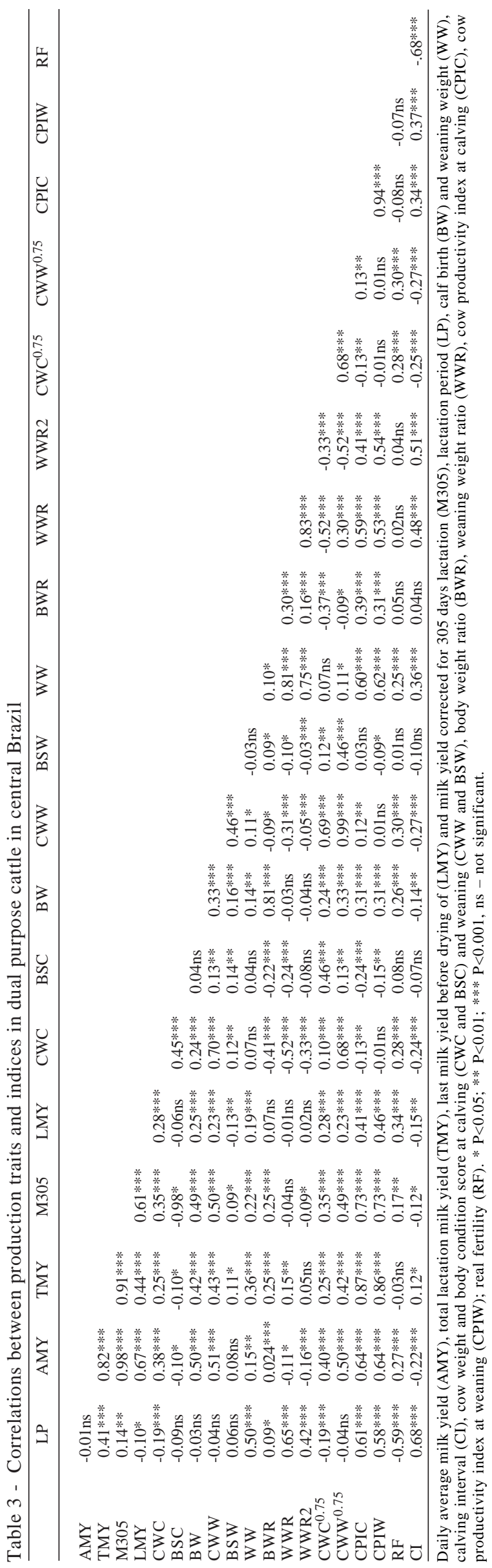

weight by various correction factors (weight, protein or energy) did not affect the final outcome. Calf sex or month of calving did not affect the index but all other factors were significant, the index improving to the $4^{\text {th }}$ and $5^{\text {th }}$ calving and then worsening. The best indices were found for cows calving in the rainy season (September to December) and thinner cows (BSC 3-5).

Lactation length had significant correlations with milk production traits $(\mathrm{P}<0.01)$, except mean daily milk production (Table 3). The correlation between it and cow weaning weight (-0.04) and calf birth weight (-0.03) were also non significant $(\mathrm{P}>0.05)$. There was a significant $(\mathrm{P}<0.05)$ negative correlation between lactation length and last production $\left(-0.10^{*}\right)$, cows with longer lactation lengths produced less at drying off. In general, the correlations between other traits were significant, except for between cow weight at calving and calf weight at weaning. The correlations between production traits were high, except between total production and last production.

Correlations between cow and calf weights and milk production traits, while significant $(\mathrm{P}<0.01)$ were of medium value (0.4-0.5) except for correlations with cow weaning weight that were low $(<0.35)$, as well as with last production. The correlations between cow and calf weights were low,
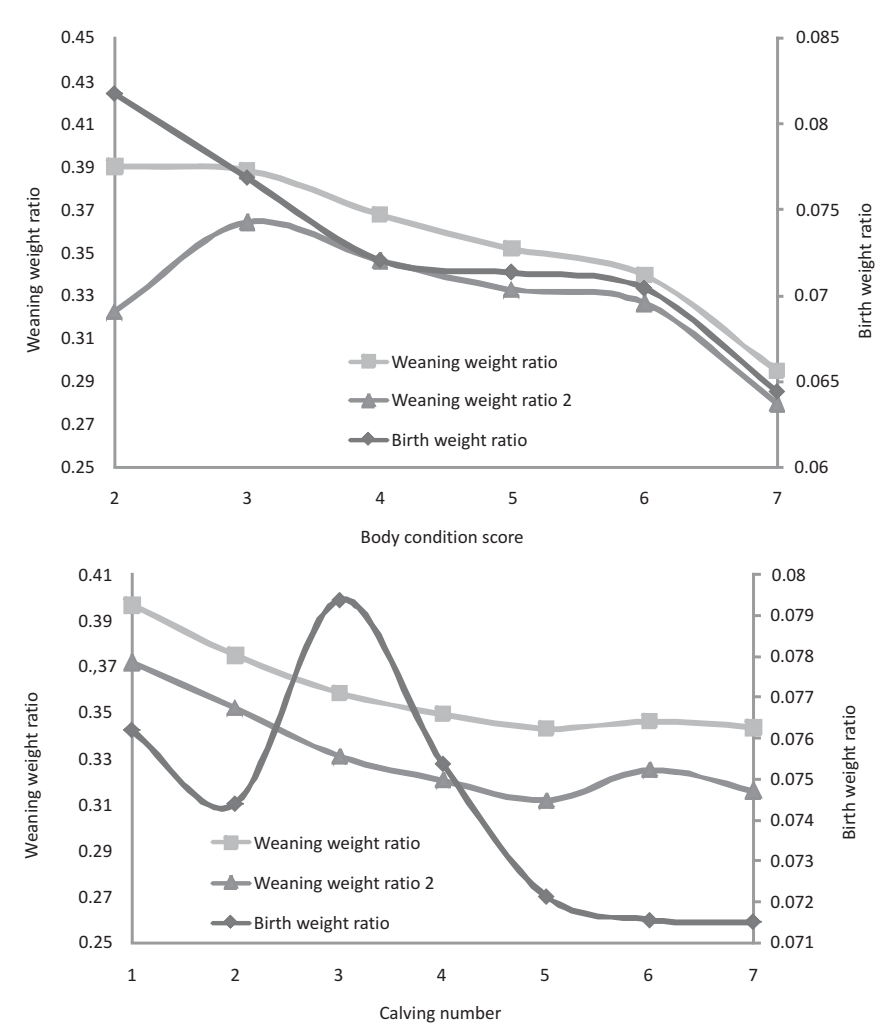

Figure 3 - Effect of cow body condition score at calving (A) and calving number (B) on productivity ratios in a dual purpose herd. 
except between cow weights at calving and weaning (0.69). Martins et al. (2003) showed that about $44 \%$ of feed costs were due to cow maintenance. The energy spent in increased maintenance is not compensated by the increase in meat sold (Cardoso et al., 2004). Lôbo et al. (2000a,b) showed that in a dual purpose system, a decrease in adult cow size had the greatest economic impact in the production system and the contributions of the meat traits for genetic profit were only superior for milk when the economic value for slaughter weight was 14 times greater than milk production. Pryce et al. (2002) found positive genetic correlation between milk production and service days and negative correlation between milk production and CI. Selection for increased milk production has a negative effect on reproductive performance (Madalena, 2008).

In general correlations between milk production traits and reproduction traits were medium to high and significant, except for lactation period with 305 day milk yield, average daily milk yield and last milk production before drying off which were low or negative. Cows with shorter lactation period had a weak but significant tendency to be dried off producing more milk and which may mean they were being dried off too early.

\section{Conclusions}

Under low input management conditions in the region of the Federal District, crossbred cows (Simmental $\times$ Gyr and Holstein Friesian $\times$ Gyr) produce approximately twice the volume of milk per lactation, calve at a younger age and have a shorter open period than Gyr cows, but calf growth rates and body condition of the cows do not differ between breeds. Seasonal variations in terms of production characteristics are marked but all groups show the same pattern of response. Further studies are needed to evaluate the effects of milking on calf growth rate, pre and post weaning in this type of system and the reasons why there are no differences between genetic groups for weaning weight.

\section{References}

ALENCAR, M.M.; TREMATORE, R.L.; OLIVEIRA, J.A.L. et al. Desempenho produtivo de vacas da raça nelore e cruzadas Charolês x Nelore, Limousin x Nelore e Tabapuã x Gir. Revista Brasileira de Zootecnia v.26, p.467-472, 1997.

ASSIS, A. G.; STOCK, L. A.; CAMPOS, O. F. et al. Sistemas de produção de leite no Brasil. Juiz de Fora: Embrapa Gado de Leite, 2005. 6p. (Circular técnica, 85).

BARBOSA, S.B.P.; MANSO, H.C.; SILVA, L.O.C. Estudo do período de lactação em vacas holandesas no Estado de Pernambuco. Revista da Sociedade Brasileira de Zootecnia, v.23, p.465-475, 1994.
BARBOSA, P.F.; BUENO, R.S. Sistemas mistos de produção de leite e carne bovina. In: SIMPÓSIO SOBRE MANEJO E NUTRIÇÃO DE GADO DE LEITE, 2000, Goiânia. Anais... Goiânia, 2000. p.53-68.

CAMPELLO, C.C.; MARTINS FILHO, R.; LOBO, R.N.B. Intervalo de partos e fertilidade real em vacas Nelore no Estado do Maranhão. Revista Brasileira de Zootecnia, v.28, p.474-479, 1999.

CAMPOS, J.M.S. Aspectos reprodutivos e produtivos em um sistema de produção de leite na microregião de Viçosa, Estados de Minas Gerais. 1987. 109f. Dissertação (Mestrado em Zootecnia) - Universidade Federal de Viçosa, Viçosa, MG

CARDOSO, R.C.; VALADARES FILHO, S.C.; COELHO da SILVA, J.F. et al. Consumo e digestibilidades aparentes totais e parciais de rações contendo diferentes níveis de concentrado, em novilhos F1 Limousin x Nelore. Revista Brasileira de Zootecnia, v.29, p.1832-1843. 2000.

CARDOSO, V.L.; NOGUEIRA, J.R.; VERESI FILHO, A.E. et al. Objetivos de seleção e valores econômicos de características de importância econômica para um sistema de produção de leite a pasto na região sudeste. Revista Brasileira de Zootecnia, v.33, p.320-327, 2004

COLLIER, R.J.; VICINI, J.L.; KNIGHT, C.D. et al. Impact of somatotropins on nutrient requirements in domestic animals. Journal of Nutrition, v.122, p.855-860, 1992.

COULIBALY, M.; NIALIBOULY, O. Effect of suckling regime on calf growth, milk production and offtake of zebu cattle in Mali. Tropical Animal Health and Production, v.30, n.3, p.179-189, 1998.

CUBAS, A.C.; PEROTTO, D.; ABRAHÃO, J.J.S. et al. Desempenho até a desmama de bezerros Nelore e cruzas com Nelore. Revista Brasileira de Zootecnia, v.30, n.3, p.694-701, 2001.

DECHOW, C.D.; ROGERS, G.W.; CLAY, J.S. Heritabilities and correlations among body condition scores, production traits, and reproductive performance. Journal of Dairy Science, v.84, p.266-275, 2001

DECHOW, C.D.; ROGERS, G.W.; CLAY, J.S. Heritability and correlations among body condition score loss, body condition score, production and reproductive performance. Journal of Dairy Science, v.85, p.3062-3070, 2003.

DREWRY, K.J.; BROWN, C.J.; HONEA, R.S. Relationships among factors associated with mothering ability in beef cattle. Journal of Animal Science, v.18, p.938-946, 1959.

EUCLIDES FILHO, K. Cruzamentos em gado de corte. Revista dos Criadores, v.786, p.15-25, 1995.

EVANS, R.D.; DILLON, P.; SHALLOO, L. et al. An economic comparison of dual-purpose and Holstein-Friesian cow breeds in a seasonal grass-based system under different milk production scenarios. Irish Journal of Agriculture and Food Research, v.43, p.1-16, 2004.

FACÓ, O.; LÔBO, R.N.B.; MARTINS FILHO, R. et al. Análise do desempenho produtivo de diversos grupos genéticos Holandês x Gir no Brasil. Revista Brasileira de Zootecnia, v.31, p.1944-1952, 2002.

FACÓ, O.; LÔBO, R.N.B.; MARTINS FILHO, R. et al. Idade ao primeiro parto e intervalo de partos de cinco grupos genéticos Holandês x Gir no Brasil, Revista Brasileira de Zootecnia, v.34, p.1920-1926, 2005.

FAO. First expert consultation on trypanotolerance and breeding of trypanotolerant animals. Rome: FAO Animal Production and Health Division, 1976. 45p.

FAO/ILCA/UNEP. Trypanotolerant livestock in West and Central Africa. Rome: FAO, 1980. v.1. 146p. (FAO Animal Production and Health Paper 20/1).

FNP Institute. Anualpec. 2008. 380p.

FRANZO, V.; PIMENTEL, M.A.; JARDIM, P.O.C. et al. Efeito do peso ao parto sobre a produção de leite e eficiência individual em novilhas primíparas Hereford e cruzas. Revista Brasilera de Agrociência, v.7, p.213-216, 2001. 
FREITAS, A.F.; MADELENA, F.E.; MARTINEZ, M.L. Age at first calving and calving interval of Holstein-Friesian and crossbred Holstein-Friesian:Gir Pesquisa Agropecuaria Brasileira, v.15, p.101-105, 1980.

FRIES, L.A.; ALBUQUERQUE, L.G. Prenhez aos catorze meses: presente e futuro. Elementos do componente genético. In: REUNIÃO ANUAL DA SOCIEDADE BRASILEIRA DE ZOOTECNIA, 36., 1999, Porto Alegre. Anais Eletrônicos... Porto Alegre: SBZ, 1999.

GLORIA, J.R.; BERGMANN, J.A.G.; QUIRINO, C.R. et al. Curvas de lactação de quatro grupos genéticos de mestiças Holandês-Zebu. Revista Brasileira de Zootecnia, v.39, p.2160-2165, 2010.

GOMES, S.T. Diagnostico e perspectivas da produção de leite no Brasil. In: VILELA, D.; BRESSAN, M.; CUNHA, A.C. (Eds.) Cadeia de lácteas no Brasil: restrições ao seu desenvolvimento. Brasília: MCT/CNPq; Juiz de Fora: EMBRAPA Gado de Leite, 2001. p.21-38.

GUIMARAES, J.D.; ALVES, N.G.; COSTA, E.P. et al. Eficiências reprodutiva e produtiva em vacas das raças Gir, Holandês e cruzadas Holandês x Zebu. Revista Brasileira de Zootecnia, v.31, p.641-647, 2002.

HANSEN, P.J.; THATCHER, W.W.; EALY, A.D. Methods for reducing effects of heat stress on pregnancy. In: Van HORN, H.H.; WILCOX, C.J. (Eds.) Large dairy herd management. Savoy: American Dairy Science Association, 1992. p.116-125.

HANSEN, M.; LUND, M.S.; SØRENSEN, M.K. et al. Genetic parameters of dairy character, protein yield, clinical mastitis, and other diseases in the Danish Holstein cattle. Journal of Dairy Science, v.85, p.445-452, 2002.

INSTITUTO BRASILEIRO DE GEOGRAFIA E ESTATÍSTICA - IBGE [2004]. Banco de dados. Available at: <http://www.sidra.ibge.gov.br> Accessed on: Nov. 12, 2009.

KARG, H. Physiological impact on fertility in cattle. In: EUROPEAN ASSOCIATION FOR ANIMAL PRODUCTION, 1980, Munich. Proceedings... Munich, 1980. 31p.

KÖPPEN, W. Climatologia: con un estudio de los climas de la tierra. México: Fundo de Cultura Econômica, 1948. 479p.

LEMOS, A.M.; VERNEQUE, R.S.; TEODORO, R.L. et al. Efeito da estratégia de cruzamentos sobre características produtivas e reprodutivas em vacas do sistema mestiço do CNPGL-EMBRAPA Revista Brasileira de Zootecnia, v.26, p.704-708, 1997.

LÔBO, R.B. Programa de melhoramento genético da raça Nelore. 2.ed. Ribeirão Preto: FINEP, 1994. 100p.

LÔBO, R.N.B.; PENNA, V.M.; MADALENA, F.E. Avaliação de um esquema de seleção para bovinos zebus de dupla aptidão. Revista da Sociedade Brasileira de Zootecnia, v.29, p.1349-1360, 2000a.

LÔBO, R.N.B.; MADALENA, F.E.; PENNA, V.M. Avaliação de esquemas de seleção alternativos para bovinos zebus de dupla aptidão. Revista Brasileira de Zootecnia, v.29, p.1361-1370, 2000b.

LÓPEZ-GATIUS, F. Is fertility declining in dairy cattle? A retrospective study in northeastern Spain, Theriogenology, v.60, p.89-99, 2003.

MADALENA, F.E.; HIJONOSA, A. Reproductive performance of Zebu compared with Charolais x Zebu females in a humid tropical climate. Animal Production, v.23, p.55-62, 1976.

MADALENA, F.E.; FREITAS, A.F.; MARTINEZ, M.L. Comparative evaluation of milk production in Holstein-Friesian and HolsteinFriesian x Gir cows. (Translated title). In: WORLD CONFERENCE ON ANIMAL PRODUCTION, 4., 1978, Buenos Aires. Proceedings... 1978. v.2, p.650-658.

MADALENA, F.E.; TEODORO, R.L.; LEMOS, A.L. et al. Programa nacional de Melhoramento Genético no CNPGL. II Resultados parciais do projeto "Estratégia de cruzamentos entre raças leiteiras na região Sudeste”. In: BRAZILIAN SYMPOSIUM ON BREEDING DAIRY CATTLE IN THE TROPICS, 1983, Juiz de Fora. Proceedings... Juiz de Fora, 1983. p.43-69.

MADALENA, F.E.; AGYEMANG, K.; CARDELLINO, R.C. et al. Genetic improvement in medium- to low-input systems of animal production. Experiences to date. In: WORLD CONGRESS ON GENETICS APPLIED TO LIVESTOCK PRODUCTION, 7., 2002, Montpellier, France. Communication... Montpellier: 2002. p.25-28 (session 25).

MADALENA, F.E. [2008]. How sustainable are the breeding programs of the global main stream dairy breeds? - The LatinAmerican situation. Livestock Research for Rural Development, v.20, article \#19. Available at: <http://www.cipav.org.co/lrrd/ lrrd20/2/mada20019.htm>. Accessed on: Aug. 21, 2008.

MARTINS, G.A.; MADALENA, F.; BRUSCHI, J.H. et al. Objetivos econômicos de seleção de bovinos de leite para fazenda demonstrativa na Zona da Mata de Minas Gerais. Revista Brasileira de Zootecnia, v.32, p.304-314, 2003.

MARTINS, G.A.; MADALENA, F.; BRUSCHI, J.H. et al. Estimativas de parâmetros de cruzamentos para peso de fêmeas Holandês/Gir Revista Brasileira de Zootecnia, v.33, n.6, p.1703-1710, 2004 (supl. 1).

MCMANUS, C.; SAUERESSIG, M.G.; FALCÃO, R.A. Componentes reprodutivos e produtivos no rebanho de corte da EMBRAPA Cerrados. Revista Brasileira de Zootecnia, v.31, p.648-657, 2002.

MCMANUS, C.; TEIXEIRA, R.A.; DIAS, L.T. et al. Características produtivas e reprodutivas de vacas Holandesas e mestiças Holandês $\times$ Gir no Planalto Central. Revista Brasileira de Zootecnia, v.37, p.819-823, 2008.

MCMANUS, C.; PRESCOTT, E.; PALUDO, G.R. et al. Heat tolerance in naturalized Brazilian cattle breeds. Livestock Science, v.120, p.256-264, 2009.

MENDONÇA, G.; PIMENTEL, M.A.; CARDELLINO, R.A. et al. Época de nascimento, genótipo, e sexo de terneiros cruzas taurinos e zebuínos sobre o peso ao nascer, a desmama e eficiência individual de primíparas Hereford. Ciência Rural, v.33, p.1117-1121, 2003.

MONTIEL, F.; GALIINA, C.S.; LAMOTHE, C. et al. Effect of a feed supplementation during the mid-lactating period on body condition, milk yield, metabolic profile and pregnancy rate of grazing dual-purpose cows in the Mexican humid tropic. Archivos de Medicina Veterinária, v.39, n.3, p.207-213, 2007.

OLIVEIRA, V.C.; FONTES, C.A.A; SIQUEIRA, J.G. et al. Produção de leite e desempenho dos bezerros de vacas nelores e mestiças. Revista Brasileira de Zootecnia, v.36, p.2074-2081, 2007.

ORTEGA, L.E.; WARD, R.W.; ANDREW, C.O. Technical efficiency of the dual purpose cattle system in Venezeula. Journal of Agricultural Applied Economy v.39, p.719-733, 2007.

PARRA, O.; OJEDA, A.; COMBELLAS, J. et al. Blood metabolites and their relationship with production variables in dual-purpose cows in Venezuela. Preventative Veterinary Medicine, v.38, p.133-145, 1999.

PEROTTO, D.; ABRAHÃO, J.J.S.; KROETZ, I.A. Intervalo de partos de fêmeas bovinas Nelore, Guzerá x Nelore, Red Angus $\mathrm{x}$ Nelore, Marchigiana x Nelore e Simental x Nelore. Revista Brasileira de Zootecnia, v.35, p.733-741, 2006a

PEROTTO, D.; MIYAGI, A.P.; SOUZA, J.C. Estudos de características reprodutivas de animais da rala canchim criados a pasto, no estado de Paraná, Brasil. Archives of Veterinary Science, v.11, p.1-6, 2006b.

PRYCE, J.E.; COFFEY, M.P.; SIMM, G. The relationship between body condition score and reproductive performance. Journal of Dairy Science, v.84, p.1508-1515, 2001.

PRYCE, J.E.; COFFEY, M.P.; BROTHERSTONE, S.H. et al. Genetic relationships between calving interval and body condition score conditional on milk yield. Journal of Dairy Science, v.85, p.1590-1595, 2002.

QUEIROZ, S.A.; GIANONNI, M.A.; RAMOS, A.A. et al. Efeitos genéticos e de ambiente sobre a duração do intervalo entre partos de bovinos mestiços holandeses na região da São Carlos, estado de São Paulo. Revista da Sociedade Brasileira de Zootecnia, v.15, n.6, p.486-474, 1986.

RAMOS, A.A. Estudo das características reprodutivas de zebuínos leiteiros da raça Gir nos trópicos. 1984. $224 \mathrm{f}$. Tese - Universidade Estadual de São Paulo, Brasil. 
RANDEL, R.D. Nutrition and postpartum rebreeding in cattle. Journal of Animal Science, v.68, p.853-862, 1990

RESTLE, J.; MENEZES, L.F.G.; ARBOITTE, M.Z. et al. Características das partes não-integrante da carcaça de novilhos 5/6 Nelore 3/8 Charolês abatidos em três estádios de desenvolvimento. Revista Brasileira de Zootecnia, v.34, p.1339-1348, 2005.

RUAS, J.R.M.; CARVALHO, B.C.; SILVA FILHO, J.M. et al. Effect of the maternal genetic basis and of the calving season on productive variables of primiparous Holstein x Zebu cows. Arquivo Brasileiro de Medicina Veterinária e Zootecnia, v.59, p.218-224, 2007.

SILVEIRA, J.C.; MCMANUS, C.; MASCIOLI, A.S. et al. Fatores ambientais e parâmetros genéticos para características produtivas e reprodutivas em um rebanho nelore no estado do Mato Grosso do Sul. Revista Brasileira de Zootecnia, v.33, p.1432-1444, 2004.

SOUZA, G.N.; BRITO, J.R.F.; FARIA C.J. Qualidade do leite de rebanhos bovinos localizados na região sudeste: Espírito Santo, Minas Gerais, Rio de Janeiro, Janeiro/2007 a junho/2008. In: MESQUITA, A.J.; DÜRR, J.W.; COELHO, K.O. (Eds.) Perspectivas e avanços da qualidade do leite no Brasil. Goiânia: Talento, 2006. 352p.
SZÉCHY, M.L.M.; BENEVIDES FILHO, I.M.; SOUZA, L.M. Idade ao primeiro parto, intervalo de partos e peso ao nascimento de um rebanho Nelore. Revista Brasileira de Ciência Veterinária, v.2, p.47-49, 1995.

TEODORO, R.L.; MILAGRES, J.C.; FONTES, C.A.A. et al. Duração média do intervalo de partos, produção de leite, gordura e proteína por dia de intervalo de partos em vacas mestiças Revista da Sociedade Brasileira de Zootecnia, v.22, p.481-487, 1993.

TEODORO, R.L.; MILAGRES, J.C.; CARDOSO, R.M. et al. Período de lactação e produção de leite, gordura e proteína ajustados para 305 dias de lactação em vacas mestiças Europeu-Zebu. Revista da Sociedade Brasileira de Zootecnia, v.23, p.274-280, 1994.

VEERKAMP R.F.; OLDENBROEK, J.K.; VAN DER GAAST, H.J. et al. Genetic correlation between days until start of luteal activity and milk yield, energy balance, and live weights. Journal of Dairy Science, v.83, p.577-583, 2000.

VERCESI FILHO, A.E.; MADALENA, F.E.; ALBUQUERQUE, L.G. et al. Parâmetros genéticos entre características de leite, de peso e a idade ao primeiro parto em gado mestiço leiteiro (Bos taurus x Bos indicus). Arquivo Brasileiro de Medicina Veterinária e Zootecnia, v.59, n.4, p.983-990, 2007.

WILDMAN, O.E.E.; JONES, G.M.; WAGNER, P.E. A dairy cow body condition scoring system and its relationship to selected production characteristics. Journal of Dairy Science, v.65, p.495-501, 1982. 